\title{
The Strategic Role of Engagement and Positive Workplace to Sustain Employee Performance
}

\author{
Septiningtyas Pramesthi Widyasari \\ Dept. of Management, Faculty of Economics, Universitas Islam Sultan Agung \\ Indonesia \\ Olivia Fachrunnisa (Corresponding author) \\ Dept. of Management, Faculty of Economics, Universitas Islam Sultan Agung \\ Indonesia
}

Received: Dec. 25, 2021 Accepted: Jan. 26, 2022 Online published: Feb. 14, 2022

doi:10.5296/jpag.v12i1.19374 URL: https://doi.org/10.5296/jpag.v12i1.19374

\begin{abstract}
Employee performance is an important factor for a company to achieve objectives, gain competitive advantage and finally winning the competition. Even for a company which has been established for more than 20 years, employee performance still becomes challenge. A good relationship between leader and member is one of the key factors to improve employee performance. A company needs to ensure that employees give their best performance and meet the expectation. The purpose of this study is to develop model to improve employee performance with high quality of Leader-Member Exchange (LMX) and Perceived Organizational Support (POS) which mediates by work engagement. Data were collected from 100 respondents of permanent employees in a teak furniture manufacturing company in Semarang, Central Java Province, Indonesia. The method used to analyze the hypotheses was Partial Least Square (PLS). This study concludes that positive workplace which contains Leader-Member Exchange (LMX), Perceived Organizational Support (POS), and Work Engagement, have a positive and significant influences on Employee Performance. Work Engagement also found has influence effect on mediating between LMX and POS with Employee Performance.
\end{abstract}

Keywords: employee performance, work engagement, leader-member exchange, perceived organizational support 


\section{Introduction}

Current business situation required all companies to compete more than ever in order to survive and come as winner in the competition. We are not only talking competition in terms of customer basic expectation like quality, delivery and cost of the product or service, but also other dominant factors like product innovation, product sustainability, social and ethical compliances, the use of effective communication system, utilization of new technology and information system as well as human resources management. Human is the most important resource that should be well managed and maintained in the first place. It all started from recruitment process and continues with people development program like training, coaching and mentoring to ensure their competencies always meet the latest requirements. Talent management and succession plan also part of strategies implemented by many organizations to guarantee business continuity. All of these good programs and strategies will be evaporated if not well monitored, evaluated and continuously improved. Periodic evaluation must be performed as a tool to make sure that employees deliver maximum performance for the company and necessary action should be taken based on the result. If companies aim to gain competitive advantage, employee performance is the key factor to achieve it (Brhane \& Zewdie, 2018; Indriastuti \& Fachrunnisa, 2021).

There are several factors affecting employee performance, one of them is Leader-Member Exchange (LMX). In this relationship scheme, leader has a big and important role in developing mutual relationship with each member. This relationship will bring direct affect to the work of both parties. A good quality relationship between leader and member will form work engagement and therefore they will work better in various work roles carried out in the organization (Chaurasia \& Shukla, 2014). In contrary, a bad quality relationship will build a wall between leader and member which affecting performance of each individual and eventually performance of team and company. Trust is the foundation of LMX and one of the key factors to build work engagement (Chughtai \& Buckley, 2011). In order to earn trust and professional respect, leaders need to show their loyalty to members in daily work-related interaction. Employee who has high-quality relationship with its leader feels close to the organization (Liu et al., 2013). This sense of closeness will drive them to deliver a good performance.

Furthermore, other factor affecting employee performance is Perceived Organizational Support (POS). When someone realizes the attention, care, support, and recognition of the organization for their well-being, they will devote themselves to be involved in organizational activities by welcoming difficult tasks, giving high effort and loving work in return for their perception of organizational support (Baset \& Karim, 2021). Employees will give their best version without any hesitation. POS plays significant role on relationship between employee and organization. Hence, it is important for companies to develop a good program and explicitly show its support to employees. Support given by companies will enhance employee engagement with their role and increase their competencies which eventually will increase productivity and performance (Fachrunnisa et al., 2021).

Employees will deliver good performance if they engaged with their work. Work engagement 
is not something that can happen instantly without any effort. It needs effort and involvement from both employee and employer. The commitment from company to provide a safe and supportive working environment will drive employee's motivation towards work. If the employee feels motivated, they will be engaged with the work. An engaged employee will have a positive feeling, find the meaning of work and all other things related to happiness and well-being (Martínez-Martí \& Ruch, 2017). Furthermore an engaged employee has a sense of energy and an effective relationship with their work, they view work as a challenge instead of stress and demands (W. B. Schaufeli, 2012). This positive kind of views will bring benefit to company.

Research focusing on sustaining the employee performance has been widely discussed, however, only a few of them considering positive workplace environment factors such as Leader-Member Exchange (LMX) and Perceived Organizational Support (POS). Previous researchers found that there is a significant effect of LMX on employee performance (Audenaert et al., 2016; Reb et al., 2019; Tanskanen et al., 2019; Wang et al., 2016), but other researchers on their studies found the opposite outcome where there is no significant effect of LMX towards employee performance (Adi et al., 2018; Insan \& Masmarulan, 2021). Based on the research gap and explanation above, this study aims to analyze the strategic role of positive workplace environment factors namely Leader-Member Exchange (LMX) and Perceived Organizational Support (POS) in improving employee performance by considering Work Engagement as mediating variable. This study will compile a conceptual model that describes the interrelationships between these variables.

\section{Literature Review and Hypotheses Development}

\subsection{Leader-Member Exchange (LMX), Work Engagement and Employee Performance}

Leader-Member Exchange (LMX) is an activity that focuses on the quality of dyadic relationship between superiors and subordinates in the work environment, where leaders can build relationships with varying intensity with each member in the group (Lee, 2020). When the quality of LMX is better, subordinates can obtain more information, direction, advice and feedback from their superiors which could lead to better performance (Lin et al., 2017). LMX also suggested as an important source of motivation to improve performance (Selvarajan et al., 2018). Based on this, leaders play an important role in developing employee attitude towards the organization and engagement with their work (Ferguson et al., 2015). Employees who have a good working relationship with their superiors are seen as more likely to have greater job satisfaction, decreased levels of intention to leave, and higher productivity which leads to improved performance (C. J. Wang, 2016). Organization needs to ensure that employees have engagement with work through its leaders. This can be facilitated by developing sustain relationship between leaders and subordinates. Every leader should act as representative of management by being a role model to its member. Leader-Member Exchange (LMX) focuses on a two-ways relation between leader and member where the quality of this relationship predicting several results on employee, one of them is a good performance (Martin et al., 2016). Considering that reason, leaders need to maintain good relation with subordinates in order to get positiveimpact on performance. In contrary, a bad 
relationship between leaders and subordinates will bring impact on employee work attitudes, including performance and their loyalty to company (Arrasyid et al., 2019). A good leader-member exchange can be demonstrated by providing opportunities for subordinates to express their ideas, have discussion and furthermore find solution to their problems, which in turn can align their personal goals with organizational goals (Sharifkhani et al., 2016). Employees who shared the same goals with organization will be more engaged to work and eventually will have a better performance.

The strength of relation between leader and member will lead to productivity, motivation and high performance (Brhane \& Zewdie, 2018). The study conducted by Gottfredson and Aguinis (2017) found that Leader-Member Exchange (LMX) is an important factor underlying the performance of employee. Furthermore Kim and Koo (2017) also found that employees who feel high-quality relationship with their leaders will be more engaged with work and more innovative in doing tasks. This is in line with study from Breevaart et al. (2015) which also found that high quality LMX promotes work engagement and better employee performance. Based on several previous studies it can be concluded that Leader-Member Exchange (LMX) has an influence on Work Engagement and also influence on Employee Performance.

\section{H1: Leader-Member Exchange (LMX) positively relates to Work Engagement}

\section{H2: Leader-Member Exchange (LMX) positively relates to Employee Performance}

\subsection{Perceived Organizational Support (POS), Work Engagement and Employee Performance}

Employees are the most important asset of company, hence they need to be treated and maintained as good as possible at all cost. As a human being, employees want to be appreciated, respected, noticed and recognized for their contribution to company. Perceived Organizational Support (POS) refers to employees' perceptions of how their contributions valued and their well-being provided by the organization (Beheshtifar \& Herat, 2013). Employees who are well treated by organization will show their appreciation by having sense of duty to repay the organization with extra effort (Jeong \& Kim, 2021). High level of POS which perceived by employees will increase their job attitudes, behavior and engagement (Caesens \& Stinglhamber, 2014). Work engagement shown by employees who get recognition from company. This kind of engagement will lead to better performance of employees. Employees also want their welfare to be considered by company. They always form general beliefs about how much the company values their contributions and cares about their well-being, which in turn will further strengthen loyalty and encourage their performance. Perceived organizational support will be influenced by various aspects of how company treats its employee, and this will affect the employee's perception (Eisenberger et al., 1986). Employee's perception on organizational support will accelerate their loyalty to achieve company objectives (Murthy, 2017).

According to Fachrunnisa et al. (2021) perceived organizational support will increase employee performance since they feel obligation to help organization achieve the goals. 


\section{Macrothink}

Chang et al. (2019) in his study found that Perceived Organizational Support (POS) has a positive effect on work engagement and employee performance. Employees who feel high organizational support will show optimal performance (Vatankhah et al., 2017). Based on several previous studies it can be concluded that Perceived Organizational Support (POS) has an influence on Work Engagement and also influence on Employee Performance.

\section{H3: Perceived Organizational Support (POS) positively relates to Work Engagement}

\section{H4: Perceived Organizational Support (POS) positively relates to Employee Performance}

\subsection{Work Engagement and Employee Performance}

Work Engagement defined by Schaufeli et al. (2002) as a positive and satisfying state of mind related to work which characterized by vigor, dedication, and absorption. Employees with vigor showing high level of energy and mental resilience at work, have willingness to give extra effort in work, and perseverance in difficult situation. Dedication shows by being involved in work and experiencing a sense of significance, enthusiasm, inspiration, pride, and challenge. While absorption refers to have full concentration and work happily, where time passes quickly and has difficulty getting away from work. Employees with these attitudes will improve their performance and bring many benefits to company (Knight et al., 2017). There are several reasons why engaged employees perform better than unengaged employees, one of the most compelling argument is that engaged employees often experience positive emotions, including happiness, joy, and enthusiasm (Demerouti \& Cropanzano, 2010; Monica, 2019). Employees who feel the most energetic and most dedicated are most likely to show adequate performance (Bakker et al., 2012). Based on several previous studies it can be concluded that Work Engagement has an influence on Employee Performance.

\section{H5: Work Engagement positively relates to Employee Performance}

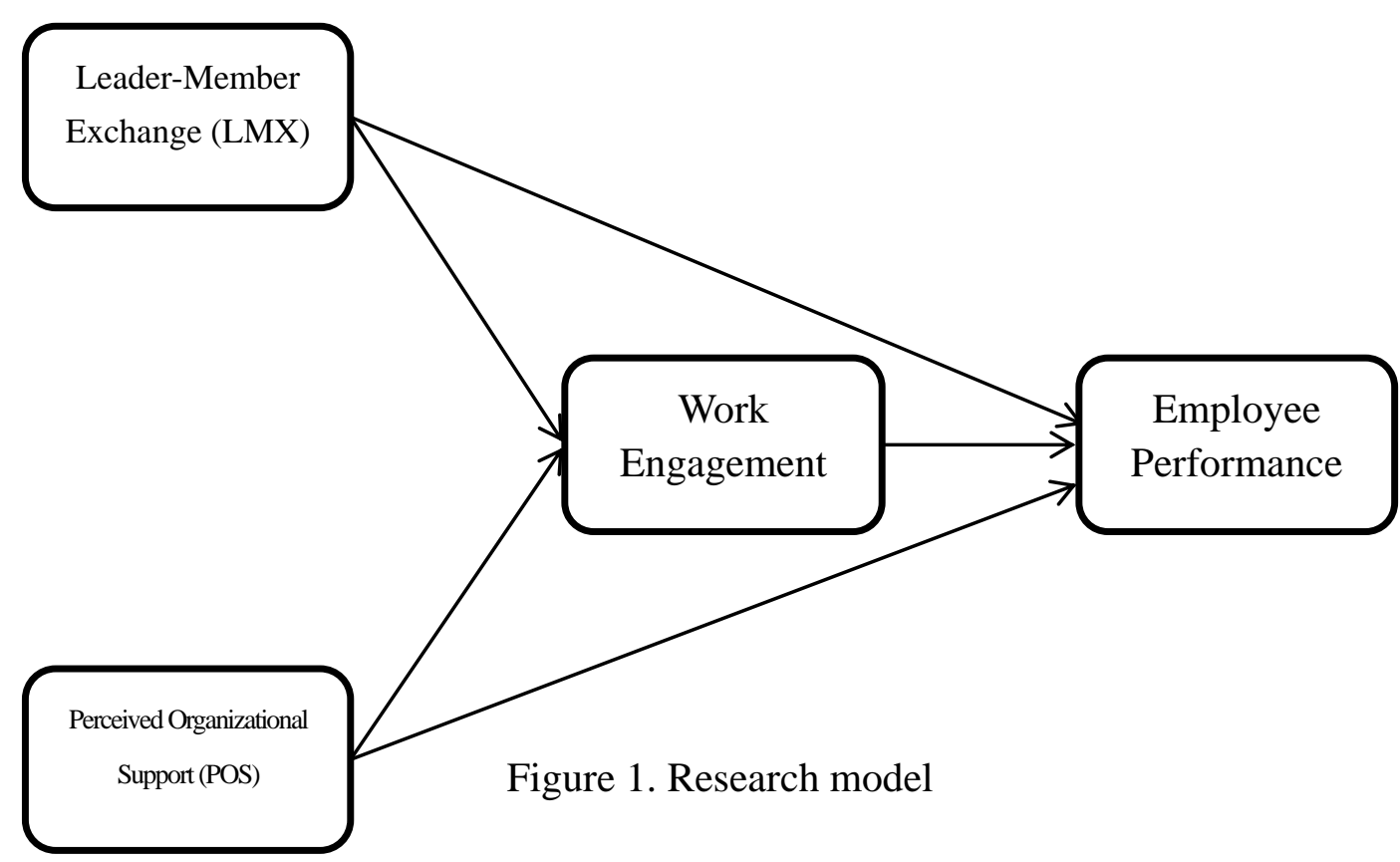




\section{Research Method}

The research was conducted on 100 respondents as permanent employees at a teak furniture manufacturing company in Semarang, Central Java Province, Indonesia which has been established for more than 20 years. The object of this research is an export-oriented company, where its performance needs to be maintained and continually improved due to high expectation from customers and tough competition from competitors. All the respondents are permanent employees who work under direct supervision where a high-quality relationship between leaders and subordinates is important to maintain and improve the performance. The reason on choosing permanent employees instead of involving temporary employees due to they have long term relationship with the leader which make them the right respondent to give their opinion about relationship with leader, work and company.

The primary data of this research was collected using questionnaire with 7 questions related to respondent's identity including name, position, gender, age, years of service, education, and department where the employee belongs to. Besides that there are main questions representing 4 variables used in this research which are Leader-Member Exchange (LMX), Perceived Organizational Support (POS), Work Engagement and Employee Performance with total 27 items using 5 Likert scale from $1=$ strongly disagree to $5=$ strongly agree. In every question respondent also asked to give explanation related to their answer. The data collected from questionnaire was analyzed using Partial Least Square (PLS).

\section{Measurement}

\subsection{Leader-Member Exchange (LMX)}

This study is focus on Leader-Member Exchange (LMX) from the perspective of member. We defined Leader-Member Exchange (LMX) as subordinates' assessment on the quality of their relationship with leaders. We measure this variable using 4 dimensions with total 11 items. The first dimension is affect with 3 items, including (1) member likes their leader as person, (2) leader is the kind of person which member would like to have as a friend, and (3) leader is someone which fun to work with. The second dimension is loyalty with 3 items, including (1) leader would defense member's work action to a superior even without complete knowledge of the issue, (2) leader would come to defense when member were attacked by others, and (3) leader would defense to others in the organization if member made an honest mistake. The third dimension is contribution with 2 items, including (1) member willing to do work for leader that goes beyond what is specified in job description and (2) member willing todo extra effort beyond those normally required. The last dimension is professional respect with 3 items, including (1) member impressed with leader's job knowledge, (2) member respects leader's knowledge and competence on the job and (3) member admires leader's professional skills. Those 11 items were adapted from Liden and Maslyn (1998). From those 11 items there were 2 out of 11 items which were not valid for further analysis with loading factors less than 0.5. These 2 invalid items were removed from data analysis. The remaining 9 items recalculated and found valid with loading factors more than 0.5 . 


\subsection{Perceived Organizational Support (POS)}

We defined Perceived Organizational Support (POS) as individual's assessment of the attention which organization pays to them. We measure this variable using 5 items, including (1) the organization appreciate contribution of employees, (2) the organization pays attention to the welfare of employees, (3) the organization cares with employees, (4) the organization pays great attention to employees and (5) the organization is proud of the success of its employees. Those 5 items are adapted from Rhoades and Eisenberger (2002). All items were valid with loading factors more than 0.5 .

\subsection{Work Engagement}

We defined work engagement as a condition in which individuals have emotional and professional ties to their work so that they can deliver maximum performance. We measure this variable using 5 items, including (1) positive thinking and satisfied with work, (2) have energy and mental resilience while working, (3) feel significance, enthusiasm, inspiration, pride, and challenge (4) fully concentrated and engrossed in work, time passes quickly, and (5) it's hard to get away from work. Those 5 items are adapted from W. Schaufeli et al. (2002). All items were valid with loading factors more than 0.5 .

\subsection{Employee Performance}

Employee performance is defined as individual's ability to complete tasks and achieve results as set by the organization. We measure this variable using 6 items which used for employee performance appraisal by the company where this research was taken place. These indicators also used in previous employee performance-related researches, including (1) achieving KPI targets (Walumbwa et al., 2011), (2) customer oriented (Korschun et al., 2014), (3) have knowledge related to work (Walumbwa et al., 2011), (4) have a positive attitude at work (Harrison et al., 2006), (5) have the ability to cooperate (Mathis \& Jackson (2006), and (6) have an awareness of health, safety and work environment (Nyambura \& Simon, 2018). All items were valid with loading factors more than 0.5 . 


\section{Result}

\subsection{Analysis of Partial Least Square (PLS)}

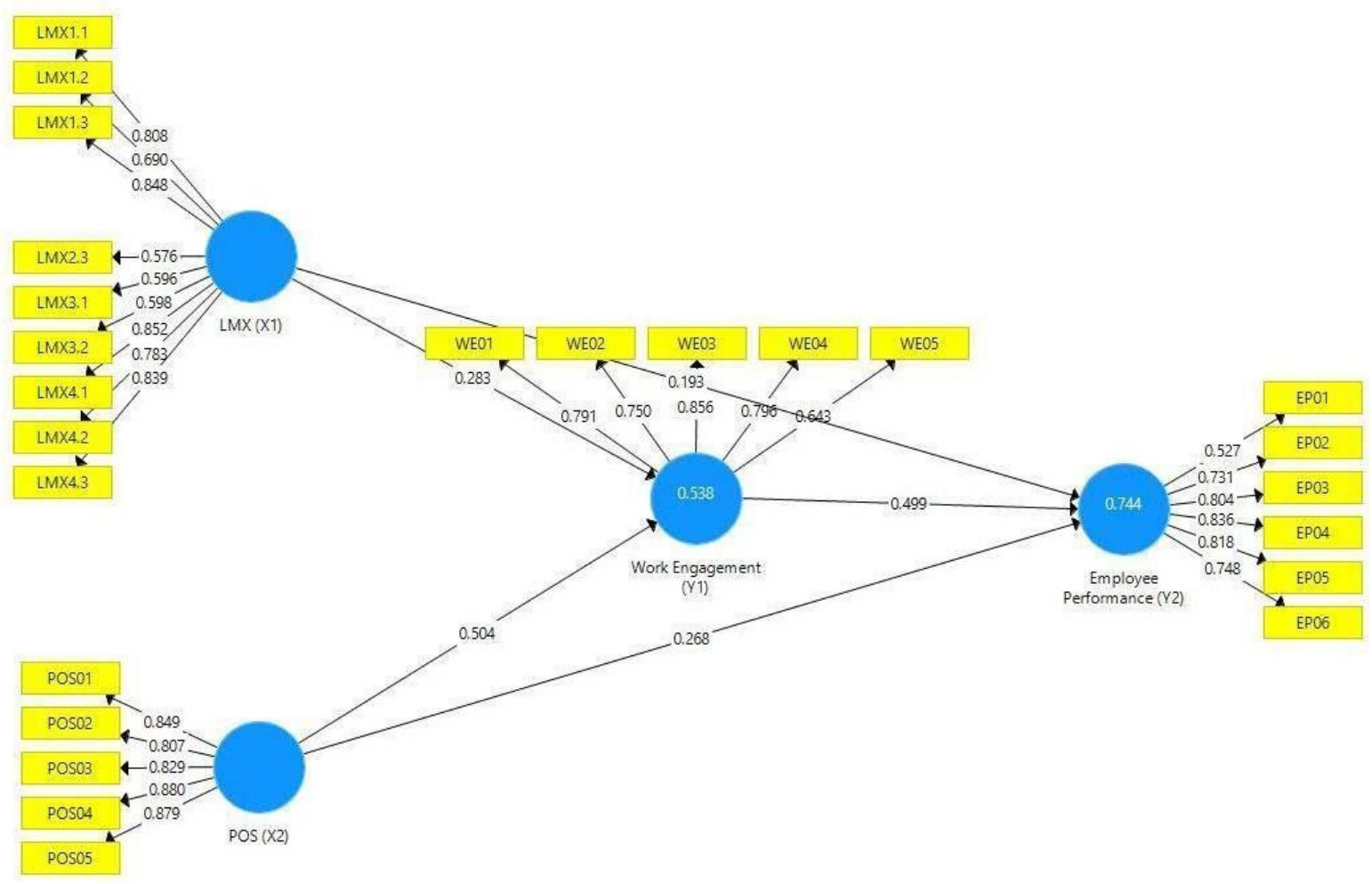

Figure 2. Structural Model

\subsection{Hypothesis Test Result}

Table 1. Coefficient Parameter, T-Statistic and P-Values

\begin{tabular}{lcccccc}
\hline Hypothesis & $\begin{array}{c}\text { Original } \\
\text { Sample }\end{array}$ & $\begin{array}{c}\text { Sample } \\
\text { Mean }\end{array}$ & $\begin{array}{c}\text { Standard } \\
\text { Deviation }\end{array}$ & T-Statistic & $\begin{array}{c}\text { P- } \\
\text { Values }\end{array}$ & $\begin{array}{c}\text { Hypothesis } \\
\text { Test result }\end{array}$ \\
\hline $\begin{array}{l}\text { LMX } \rightarrow \text { Work } \\
\text { Engagement }\end{array}$ & 0.283 & 0.287 & 0.106 & 2.679 & 0.008 & Supported \\
\hline $\begin{array}{l}\text { LMX } \rightarrow \text { Employee } \\
\text { Performance }\end{array}$ & 0.193 & 0.203 & 0.086 & 2.259 & 0.024 & Supported \\
\hline $\begin{array}{l}\text { POS } \rightarrow \text { Work } \\
\text { Engagement }\end{array}$ & 0.504 & 0.509 & 0.089 & 5.680 & 0.000 & Supported \\
$\begin{array}{l}\text { POS } \rightarrow \text { Employee } \\
\text { Performance }\end{array}$ & 0.268 & 0.262 & 0.094 & 2.856 & 0.004 & Supported \\
\hline $\begin{array}{l}\text { Work Engagement } \\
\rightarrow \text { Employee }\end{array}$ & 0.499 & 0.494 & 0.098 & 5.071 & 0.000 & Supported \\
Performance & & & & & & \\
\hline
\end{tabular}

Hypothesis 1 states that Leader-Member Exchange (LMX) is positively related to Work 
Engagement. Our results supported this view with P-values $<0.05(0.008<0.05)$ thus Ho is rejected. Coefficient value (original sample column) is positive which means that the effect is positive. It means that if employee assesses there is a good quality of relationship with their leader, they will be more engaged to their work. Hence, hypothesis 1 is supported.

Hypothesis 2 states that Leader-Member Exchange (LMX) is positively related to Employee Performance. Our results supported this view with P-values $<0.05(0.024<0.05)$ thus Ho is rejected. Coefficient value (original sample column) is positive which means that the effect is positive. It means that if employee assesses there is a good quality of relationship with their leader, it will improve their performance. Hence, hypothesis 2 is supported.

Hypothesis 3 states that Perceived Organizational Support (POS) is positively related to Work Engagement. Our results supported this view with P-values $<0.05(0.000<0.05)$ thus Ho is rejected. Coefficient value (original sample column) is positive which means that the effect is positive. It means that if the employee sees and feels that the organization support their well-being, employee will be more engaged to their work. Hence, hypothesis 3 is supported.

Hypothesis 4 states that Perceived Organizational Support (POS) is positively related to Employee Performance. Our results supported this view with P-values $<0.05(0.004<0.05)$ thus Ho is rejected. Coefficient value (original sample column) is positive which means that the effect is positive. It means that if the employee sees and feels that the organization support their well-being, it will improve their performance. Hence, hypothesis 4 is supported.

Finally hypothesis 5 states that Work Engagement is positively related to Employee Performance. Our results supported this view with P-values $<0.05(0.000<0.05)$ thus Ho is rejected. Coefficient value (original sample column) is positive which means that the effect is positive. It means that if the employee engaged with their work, their performance will be improved. Hence, hypothesis 5 is supported.

\subsection{Mediating Variable Test Result}

The test was performed to see the effect of mediating variable by measuring the Specific Indirect Effect. This test refers to the predictor effect on the outcome of the intervention by one or more variables operating sequentially (Fritz et al., 2012). The aim of this test is to find out how big the role of mediating variable, in this case is Work Engagement mediating the effect of Leader-Member Exchange (LMX) and Perceived Organizational Support (POS) on Employee Performance.

Table 2. Specific Indirect Effect

\begin{tabular}{lccccc}
\hline Hypothesis & $\begin{array}{c}\text { Original } \\
\text { Sample }\end{array}$ & $\begin{array}{c}\text { Sample } \\
\text { Mean }\end{array}$ & $\begin{array}{c}\text { Standard } \\
\text { Deviation }\end{array}$ & $\begin{array}{c}\text { T- } \\
\text { Statistics }\end{array}$ & $\begin{array}{c}\text { P- } \\
\text { Values }\end{array}$ \\
\hline $\begin{array}{l}\text { LMX } \rightarrow \text { Work Engagement } \\
\rightarrow \text { Employee Performance }\end{array}$ & 0.141 & 0.138 & 0.052 & 2.694 & 0.007 \\
\hline $\begin{array}{l}\text { POS } \rightarrow \text { Work Engagement } \rightarrow \\
\text { Employee Performance }\end{array}$ & 0.251 & 0.252 & 0.071 & 3.520 & 0.000 \\
\hline
\end{tabular}


5.3.1 Work Engagement Mediates Leader-Member Exchange (LMX) towards Employee Performance

Based on the Specific Indirect Effect analysis, which obtained the P-value of the indirect effect of Leader-Member Exchange (LMX) on Employee Performance through Work Engagement is 0.007 , which is less than 0.05 . This means that if the quality of interaction between leaders and subordinates is high, it will increase work engagement which will further improve employee performance.

\subsubsection{Work Engagement Mediates Perceived Organizational Support (POS) towards Employee Performance}

Based on the Specific Indirect Effect analysis, where the P-value of the indirect effect of Perceived Organizational Support (POS) on Employee Performance through Work Engagement is 0.000 , which is less than 0.05 . This means that if the organizational support felt by employees is higher, it will increase work engagement which will further improve employee performance.

\section{Discussion}

Research on how to improve employee performance still becomes something that interesting to do by many researchers. What make it interesting is that employee performance is the key factor for organization to achieve competitive advantage and winning the competition. Among several factors influencing employee performance, Leader-Member Exchange (LMX) found to have significant positive influence. The high-quality relationship between leaders and subordinates becomes dominant, in order to maintain good professional relation and enhance employee performances. Leaders who have the knowledge, competency and professional ability will gain more respect from subordinates. Professional respect from subordinates towards the leaders found to be the highest indicator which can improve the cooperation between leaders and subordinates. This result is consistent with study conducted by Kammerhoff et al. (2019) where leaders who encourage and support subordinates by developing high-quality LMX will motivate subordinates to continuously improve their performance and excellence. Furthermore LMX also found to have influence on work engagement. Relationship between leaders and subordinates is not merely in formal context, subordinates also wanting leaders who can position themselves as friend, easy to talk with and open to have discussion. Based on description from respondents, they want leaders who willing to absorb aspiration, give feedback, provide solution and motivate subordinates to have better performance. This kind of relationship will make employees more enthusiastic and enjoy doing their job. These results in line with study conducted by Kim and Koo (2017) where in his research on hotel found that employees who feel the quality of relationship with their superiors are more engaged with the work. That's why company should focus on developing high-quality LMX which will improve employee's attitude towards work (Naz, 2019).

Perceived Organizational Support (POS) also found to have significant positive influence on employee performance. Based on the result, employee perceived that their welfare and 
condition is taken care by company, which in return they work harder to achieve KPI target set by company. Despite their welfare which is found to be the highest indicator of POS, employees also perceived that their contribution and success are recognized by company. Recognition from company is something that really matter to employees. Based on the answer of open-ended question, employees are not always expecting appreciation in a form of monetary like bonus or salary increment. However employees also want to get compliment, career development and opportunity to access training. In exchange to that, employees pay back to company by showing a positive attitude at work, loyalty to the company and have willingness to learn new field. Employees who feel support from organization find to have better performance. These results consistent with previous study conducted by Farooqi et al. (2019) on teachers, where overall performance of teacher improved when they received organizational support from higher institution or authorities. Despite direct influence on employee performance, POS also found to have influence on wok engagement. Based on description from respondents, when employees perceived attention from company, they willing to do extra job, open with new job assignment and ready to face new challenges. This kind of attitude shows that employees have engagement with work. These results in line with previous study where employees will be more engaged to their work if they felt support from organization (Baset \& Karim, 2021; Chang et al., 2019).

Other factor which also found to have significant positive influence on employee performance is work engagement. Employees who have high engagement with work can be indicated by having energy and mental resilience at work, enjoying their work and have positive thinking mindset (W. Schaufeli et al., 2002). Engaged employees are proven to have customer-oriented attitude by doing what should be done to meet customer expectations which reflecting their performance. Based on the answer of open-ended question, customer-oriented attitude shown in daily work by meeting the deadline, providing correct and accurate data as well as complying with all requirements. Moreover an awareness to work with co-worker and leaders also shown by engaged employees (Ancarani et al., 2018).

\section{Conclusion}

Research on sustaining the employee performance has been widely discussed, however, only a few of them considering positive workplace environment factor. This research produces a comprehensive model that Leader-Member Exchange (LMX), Perceived Organizational Support (POS) and Work Engagement are the determinants for maintaining the sustainability of employee performance. The result of this study shows that Leader-Member Exchange (LMX) and Perceived Organizational Support (POS) have a direct influence on work engagement and employee performance. It also shows that work engagement mediates the influence of LMX and POS towards employee performance. This result provides empirical evidence that can be considered and used for management practice. The managerial implication obtained from this study is that leaders must aware the important of high-quality relationship with its subordinates, since Leader-Member Exchange (LMX) found to has influence on work engagement and employee performance. A high-quality LMX indicated by how well leaders can affect its subordinates, how far subordinates give their contribution and how subordinates show professional respect to leaders. Other factor indicating LMX is 
loyalty shown by leaders to subordinates. Leaders have dominant role determining the success of this relationship, since they are in higher position that have full control to subordinates. Leaders have to understand these factors in order to develop and maintain a good relation with subordinates. When leaders manage to have good relation with subordinates, it will foster employee's attitude towards work and improve their performance.

This study also found that Perceived Organizational Support (POS) has influence on work engagement and employee performance. The result clearly shows that employee who perceive support from organization in form of attention, care and recognition, found to be more engaged with work and have better performance. In order to ensure that employees perceive the support, company needs to have good program and evaluate the implementation. Evaluation is important for company to know how well the program perceived by employees. Company should be proactive in collecting feedback and input from employees, so that the supports given to employees are in line with their need. A safe communication program where employees can raise their concern and ideas on what kind of support they need will be a good choice. Company should welcoming these inputs by realize it in tangible form which can be felt by employees. When company can manage this circle in a good way, employee performance will be improved and eventually bringing benefit to company.

Other contribution of this study for HR practice is that work engagement mediates relationship between LMX and POS towards employee performance. Based on that finding, company needs to focus and combine these factors to achieve the objectives. Leaders as management representatives should able to translate company's objectives to its subordinates. They should act as role model with positive attitude by creating a safe work environment which can foster employee's engagement to work. Company also needs to make sure that the support given to employees is right on target and well perceived by them. If this combination is well implemented and managed, it will bring benefit to employees and company as well.

The result of this study may have some limitation which can be used as reference for future research. First, this study focuses on Leader-Member Exchange (LMX) from perspective of member which may not representing leader's perception on the relationship. Second, this study was based on a sample in one manufacturing company (teak furniture), which may differ from other industry or service company. The fact that the data were collected from one company, the result may limited and cannot be generalized. Third, this study using indicators of employee performance which applied in the company where the research was conducted, some of the indicators may differ from other company. Future study can be focused on Leader-Member Exchange (LMX) from the perspective of leader or from two-ways perspectives (both leader and member). In terms of respondents, future research can be conducted in multiple organizations or multiple industries so that the findings can represent broader kind of organization and increase the generalization.

\section{References}

Adi, S. T., Aju, B. I., \& Ayu, B. I. (2018). Effect of Competence, Leader-Member Exchange and Teamwork on Work Dicipline, Job Stress and Their Impact on Employee Performance of Construction Company in East Java, Indonesia. Russian Journal of Agricultural and 
Socio-Economic Sciences, 74(2), 108-114. https://doi.org/10.18551/rjoas.2018-02.08

Ancarani, A., Di Mauro, C., Giammanco, M. D., \& Giammanco, G. (2018). Work engagement in public hospitals: a social exchange approach. International Review of Public Administration, 23(1), 1-19. https://doi.org/10.1080/12294659.2017.1412046

Arrasyid, M. I., Amaliyah, \& Pandin, M. G. R. (2019). Review on Leader Member Exchange Theory: Antecedent and The Effect on Employee Performance. Preprints 2019. https://www.preprints.org/manuscript/201905.0195/v1

Audenaert, M., Decramer, A., George, B., Verschuere, B., \& Van Verschuere, T. (2016). When employee performance management affects individual innovation in public organizations: The role of consistency and LMX. International Journal of Human Resource Management, 30(5), 815-834. https://doi.org/10.1080/09585192.2016.1239220

Baset, M. A., \& Karim, D. N. (2021). Relationship between Perceived Organizational Support and Work Engagement: An Empirical Evidence from Bangladesh. The Jahangirnagar Journal of Business Studies, 9(1), 1-19

Beheshtifar, M., \& Herat, B. H. (2013). To promote employees commitment via perceived organizational support. International Journal of Academic Research in Business and Social Sciences, 3(1), 306-313

Bledow, R., Schmitt, A., Frese, M., \& Kühnel, J. (2011). The affective shift model of work engagement. Journal of Applied Psychology, 96(6), 1246-1257. https://doi.org/10.1037/a0024532

Breevaart, K., Bakker, A. B., Demerouti, E., \& Van Den Heuvel, M. (2015). Leader-member exchange, work engagement, and job performance. Journal of Managerial Psychology, 30(7), 754-770. http://dx.doi.org/10.1108/JMP-03-2013-0088

Brhane, H., \& Zewdie, S. (2018). A Literature Review on the Effects of Employee Relation on Improving Employee Performance. Journal International Journal in Management and Social Science, 6(04), 2321-1784

Caesens, G., Stinglhamber, F., \& Luypaert, G. (2014). The impact of work engagement and workaholism on well-being: The role of work-related social support. Career Development International, 19(7), 813-835. https://doi.org/10.1108/CDI-09-2013-0114

Chang, W., Wu, C., \& Weng, L. (2019). The Effect of Perceived Organizational Support on Work Engagement and Performance: A Study of International Assignees. Cross-Cultural Business Conference 2019, May, 313-321

Chaurasia, S., \& Shukla, A. (2014). Psychological Capital, LMX, Employee Engagement \& Work Role Performance. Indian Journal of Industrial Relations, 50(2), 342-357. http://www.jstor.org/stable/24549128

Chughtai, A. A., \& Buckley, F. (2011). Work engagement: Antecedents, the mediating role of learning goal orientation and job performance. Career Development International, 16(7), 
684-705. https://doi.org/10.1108/13620431111187290

Demerouti, E., Cropanzano, R., Bakker, A., \& Leiter, M. (2010). From thought to action: Employee work engagement and job performance. Work engagement: A handbook of essential theory and research, 65(1), 147-163

Eisenberger, R., Huntington, R., Hutchison, S., \& Sowa, D. (1986). Perceived organizational support. Handbook of Employee Commitment, 71(3), 333-345. https://doi.org/10.4337/9781784711740.00037

Fachrunnisa, O., Gani, A., Nurhidayati, N., \& Adhiatma, A. (2021). Cognitive engagement: a result of talent-based training to improve individual performance. International Journal of Training Research, 00(00), 1-19. https://doi.org/10.1080/14480220.2021.1990105

Farooqi, M. T. K., Ahmed, S., \& Ashiq, I. (2019). Relationship of Perceived Organizational Support with Secondary School Teachers' Performance. Bulletin of Education and Research, 41(3), 141-152

Ferguson, M., Carlson, D., \& Kacmar, K. M. (2015). Flexing Work Boundaries: The Spillover and Crossover of Workplace Support. Personnel Psychology, 68(3), 581-614. https://doi.org/10.1111/peps.12084

Fritz, M. S., Taylor, A. B., \& MacKinnon, D. P. (2012). Explanation of Two Anomalous Results in Statistical Mediation Analysis. Multivariate Behavioral Research, 47(1), 61-87. https://doi.org/10.1080/00273171.2012.640596

Gottfredson, R. K., \& Aguinis, H. (2017). Leadership behaviors and follower performance: Deductive and inductive examination of theoretical rationales and underlying mechanisms. Journal of Organizational Behavior, 38(4), 558-591. https://doi.org/10.1002/job.2152

Harrison, D. A., Newman, D. A., \& Roth, P. L. (2006). How important are job attitudes? Meta-analytic comparisons of integrative behavioral outcomes and time sequences. Academy of Management Journal, 49(2), 305-325. https://doi.org/10.5465/AMJ.2006.20786077

Indriastuti, D., \& Fachrunnisa, O. (2021). Achieving Organizational Change: Preparing Individuals to Change and their Impact on Performance. Public Organization Review, 21(3), 377-391. https://doi.org/10.1007/s11115-020-00494-1

Insan, A. N., \& Masmarulan, R. (2021). Effects of leader-member exchange and organizational culture on work engagement and employee performance. Management Science Letters, 11(3), 879-886. https://doi.org/10.5267/j.msl.2020.10.011

Kammerhoff, J., Lauenstein, O., \& Schütz, A. (2019). Leading toward harmony - Different types of conflict mediate how followers' perceptions of transformational leadership are related to job satisfaction and performance. European Management Journal, 37(2), 210-221. https://doi.org/10.1016/j.emj.2018.06.003

Kim, M. S., \& Koo, D. W. (2017). Linking LMX, engagement, innovative behavior, and job performance in hotel employees. International Journal of Contemporary Hospitality 
Management, 29(12), 3044-3062. https://doi.org/10.1108/IJCHM-06-2016-0319

Knight, C., Patterson, M., Dawson, J., \& Brown, J. (2017). Building and sustaining work engagement-a participatory action intervention to increase work engagement in nursing staff. European Journal of Work and Organizational Psychology, 26(5), 634-649. https://doi.org/10.1080/1359432X.2017.1336999

Korschun, D., Bhattacharya, C. B., \& Swain, S. D. (2014). Corporate Social Responsibility, Customer Orientation, and the Job Performance of Frontline Employees. Journal of Marketing, 78(3), 20-37. https://doi.org/10.1509\%2Fjm.11.0245

Lee, S. H. (2020). Achieving corporate sustainability performance: The influence of corporate ethical value, and LMX on employee behaviors and organizational performance. Fashion and Textiles, 7(1), 1-17. https://doi.org/10.1186/s40691-020-00213-w

Liden, R. C., \& Maslyn, J. M. (1998). Multidimensionality of leader-member exchange: An empirical assessment through scale development. Journal of Management, 24(1), 43-72. https://doi.org/10.1177/014920639802400105

Lin, W. J., Lin, C. Y., \& Chang, Y. H. (2017). The impact of coaching orientation on subordinate performance: the moderating effects of implicit person theory and LMX. Asia Pacific Journal of Human Resources, 55(1), 86-105. https://doi.org/10.1111/1744-7941.12107

Liu, Z., Cai, Z., Li, J., Shi, S., \& Fang, Y. (2013). Leadership style and employee turnover intentions: A social identity perspective. Career Development International, 18(3), 305-324. https://doi.org/10.1108/CDI-09-2012-0087

Martin, R., Guillaume, Y., Thomas, G., Lee, A., \& Epitropaki, O. (2016). Leader Member Exchange (LMX) and performance. Hurihu, 69(5), 67-121. https://doi.org/10.1111/peps.12100

Martínez-Martí, M. L., \& Ruch, W. (2017). The Relationship Between Orientations to Happiness and Job Satisfaction One Year Later in a Representative Sample of Employees in Switzerland. Journal of Happiness Studies, 18(1). https://doi.org/10.1007/s10902-016-9714-4

Monica, R. (2019). Factors influencing work engagement and its impact on task performance. International Journal of Business Excellence, 17(1), 97-129. https://doi.org/10.1504/IJBEX.2019.096913

Murthy, R. K. (2017). Perceived organizational support and work engagement. International Journal of Applied Research,3(5), 738-740. http://www.allresearchjournal.com/archives/2017/vol3issue5/PartK/3-5-140-492.pdf.

Naz., S. (2019). Role of Work Engagement and Job Performance in an LMX Environment. Market Forces, 14(2), 56-77

Nyambura, M. M., \& Simon, K. (2018). Effect of Safety Awareness Campaigns on Employee Performance in Power Transmission Companies in Kenya. International Journal of Business 
Management and Finance, 2(1), 775-784

Reb, J., Chaturvedi, S., Narayanan, J., \& Kudesia, R. S. (2019). Leader Mindfulness and Employee Performance: A Sequential Mediation Model of LMX Quality, Interpersonal Justice, and Employee Stress. Journal of Business Ethics, 160(3), 745-763. https://doi.org/10.1007/s10551-018-3927-X

Rhoades, L., \& Eisenberger, R. (2002). Perceived organizational support: A review of the literature. Journal of Applied Psychology, 87(4), 698-714. https://doi.org/10.1037/0021-9010.87.4.698

Schaufeli, W. B. (2012). Work Engagement. What Do We Know and Where Do We Go? Work Engagement in Everyday Life, Business, and Academia. Romanian Journal of Applied Psychology, 14(1), 3-10

Schaufeli, W., Salanova, M., González-romá, V., \& Bakker, A. (2002). The Measurement of Engagement and Burnout: A Two Sample Confirmatory Factor Analytic Approach. Journal of Happiness Studies, 3(1), 71-92. https://doi.org/10.1023/A:1015630930326

Selvarajan, T.T.; Singh, Barjinder; Solansky, Stephanie (2018). Performance appraisal fairness, leader member exchange and motivation to improve performance: A study of US and Mexican employees. Journal of Business Research, 85(), 142-154. doi:10.1016/j.jbusres.2017.11.043

Sharifkhani, M., Khazaei Pool, J., \& Asian, S. (2016). The impact of leader-member exchange on knowledge sharing and performance: An empirical investigation in the oil and gas industry. Journal of Science and Technology Policy Management, 7(3), 289-305. https://doi.org/10.1108/JSTPM-11-2015-0037

Tanskanen, J., Mäkelä, L., \& Viitala, R. (2019). Linking Managerial Coaching and Leader-Member Exchange on Work Engagement and Performance. Journal of Happiness Studies, 20(4), 1217-1240. https://doi.org/10.1007/s10902-018-9996-9

Vatankhah, S., Javid, E., \& Raoofi, A. (2017). Perceived organizational support as the mediator of the relationships between high-performance work practices and counter-productive work behavior: Evidence from airline industry. Journal of Air Transport Management, 59, 107-115. https://doi.org/10.1016/j.jairtraman.2016.12.001

Walumbwa, F. O., Mayer, D. M., Wang, P., Wang, H., Workman, K., \& Christensen, A. L. (2011). Linking ethical leadership to employee performance: The roles of leader-member exchange, self-efficacy, and organizational identification. Organizational Behavior and Human Decision Processes, 115(2), 204-213. https://doi.org/10.1016/j.obhdp.2010.11.002

Wang, C. J. (2016). Does LMX enhance performance in the hospitality industry?: The mediating roles of task motivation and creativity. International Journal of Contemporary Hospitality Management, 28(5), 969-987. https://doi.org/10.1108/IJCHM-10-2014-0513

Wang, D., Gan, C., \& Wu, C. (2016). LMX and employee voice: A moderated mediation model of psychological empowerment and role clarity. Personnel Review, 45(3), 605-615. 
https://doi.org/10.1108/PR-11-2014-0255

Y. Jeong \& M. Kim. Effects of perceived organizational support and perceived organizational politics on organizational performance: Mediating role of differential treatment. Asia Pacific Management Review. https://doi.org/10.1016/ j.apmrv.2021.08.002

\section{Copyright Disclaimer}

Copyright for this article is retained by the author(s), with first publication rights granted to the journal.

This is an open-access article distributed under the terms and conditions of the Creative Commons Attribution license (http://creativecommons.org/licenses/by/4.0/). 